REVIEW

\title{
Therapies intended for joint regeneration in the horse
}

\author{
Terapias con potencial regenerativo articular en el caballo
}

\author{
JA Sandoval, C López, JU Carmona* \\ Grupo de Investigación Terapia Regenerativa, Departamento de Salud Animal, \\ Universidad de Caldas, Manizales, Caldas, Colombia.
}

\begin{abstract}
RESUMEN
Las cojeras constituyen la principal causa de consulta en clínica equina y la osteoartritis (OA) representa cerca del $60 \%$ de los casos. Durante la última década se han presentado avances significativos en nuestro entendimiento de la fisiopatología de la OA. Sin embargo, se ha avanzado muy poco en el desarrollo de tratamientos efectivos que no solo alivien el dolor y la inflamación asociados al problema, sino que también limiten los cambios degenerativos o incluso promuevan la regeneración de los tejidos articulares afectados por esta enfermedad crónica inflamatoria. Por otra parte, estos tratamientos deberían ser libres de efectos adversos como trastornos gastrointestinales, daño renal e inmunosupresión. El actual conocimiento de proteínas y células comprometidas en la biología de las enfermedades musculo-esqueléticas, como la OA, han permitido el desarrollo de nuevos enfoques terapéuticos desde el punto de vista experimental y clínico. El objetivo de esta revisión es presentar estado del arte de la terapia regenerativa articular en el caballo.
\end{abstract}

Palabras clave: caballo, osteoartritis, medicina regenerativa.

\section{SUMMARY}

Lameness is the main cause of consultation in the current equine clinic, and osteoarthritis (OA) represents about $60 \%$ of cases. During the last decade, there have been significant advances in our understanding of the pathophysiology of OA. However, there has been little progress in the development of effective treatments that not only relieve pain and inflammation associated with the problem, but also limit degenerative changes, or even promote regeneration in joint tissues affected by this chronic and inflammatory disease. These treatments should be free of side effects such as gastrointestinal disorders, kidney damage and immunosuppression. Current knowledge about the proteins and cells involved in the biology of musculoskeletal diseases, such as OA, has allowed the development of new therapeutic approaches from an experimental and clinical viewpoint. The aim of this review is to present the state of the art for regenerative therapy of joints in the horse.

Key words: horse, osteoarthritis, regenerative medicine.

\section{INTRODUCTION}

Recent advances in our knowledge about the cellular and molecular biology related to the pathophysiology of chronic musculoskeletal diseases in different animal species, including humans and equines, have led to the discovery of some suggesting possibly efficacious novel treatments for these diseases (Mcllwraith 2009). The identification of key genes and proteins involved in the development of joint disease has opened a new window to achieving more effective and safer treatments with affordable costs (Sutter 2007). The current challenge is to develop therapeutic options that slow down the progress of degenerative changes in articular cartilage and other joint structures, while avoiding the adverse effects associated with conventional therapy (McIlwraith 2009). However,

Accepted: 04.07.2013.

* Calle 65 No 26-10, Manizales, Caldas, Colombia; carmona@ucaldas.edu.co economic, legal and ethical constraints restrict the use of biological therapies (biopharmaceuticals) that most probably could be used successfully in these diseases.

Osteoarthritis (OA) has always been treated symptomatically in the horse using conventional therapies such as non-steroidal anti-inflammatory drugs (NSAID) and corticosteroids (CS). In recent years, there has been a growing interest in the use of nutraceuticals, such as chondroitin sulfate and glucosamine, amongst others (Neil et al 2005, Coudry et al 2007, Byron et al 2008, Gough et al 2010). These substances are intended to slow down the progression of joint damage and reduce the need for NSAID and CS (Shoemaker 2004, Carmona and Giraldo 2007, McIlwraith 2009), chronic use of which frequent occurrence of intestinal bleeding, hemorrhagic ulcerative colitis, nephropathy and immunosuppression (Malone 2002).

Equine OA and the pathological conditions associated with this disease show similar biochemical and clinical manifestations as in humans (Frisbie 2005, Mcllwraith 
2008, Fox et al 2010). OA can be classified as either primary or secondary. Primary OA is a rare per se genetic disorder that has been rarely reported in the horse (Reynard and Loughlin 2012, Sandell 2012). Secondary OA may appear as a sequel of joint infection or osteochondrosis (Carmona and Prades 2009, Carmona et al 2010). However, this disease can also be triggered by factors such as exaggerated joint overload, joint instability, single or continued trauma, hypoxia, overweight and aging, amongst others. All of the aforementioned factors or pathologic conditions can be responsible for dysregulating the expression of several genes, which leads to the overproduction of certain catabolic cytokines, mainly interleukin 1 (IL-1) and tumor necrosis factor alpha (TNF- $\alpha$ ) and, subsequently, the activation of pro-inflammatory nuclear factors (e.g: nuclear factor kappa beta -NFKb-) that induce joint destruction, mediated and ultimately perpetuated by matrix metalloproteinases (MMP), eicosanoids and free radicals. All of these molecules contaminate the joint space, and may either lead to chondrocyte death or decrease the metabolic capacity of these cells. In these conditions, the capacity of the extracellular matrix (ECM) to respond properly to challenges is impaired and a vicious cycle is started in which the damage to the joint increases (Argüelles et al 2005, Carmona and Giraldo 2007, Mcllwraith 2009). Clinical signs of the disease include synovial effusion, limited joint mobility and joint deformation in chronic cases (Patan-Zugaj and Edinger 2009, Carmona et al 2010, Sellam and Berenbaum 2010).

There is no doubt that the era of symptomatic therapy for chronic musculoskeletal diseases such as OA is fading away and that new therapeutic ideas are heralding a new era of regenerative therapy (medicine) (Sutter 2007). However, considerable research efforts are still necessary before the actual expectations of these new therapies can be substantiated. Double-blind randomized clinical studies and strictly controlled research using animal models for musculoskeletal disease will be necessary to show the translational value of these techniques and their potential for application in human beings, so overcoming international legal frameworks that actually limit the clinical use of these therapies (Frisbie 2005, Kofron and Laurencin 2005, McIlwraith 2008). This review addresses the main regenerative treatments (experimental and clinical) that have been proposed as regenerative therapies for joint disease in the horse.

\section{JOINT REGENERATIVE THERAPY}

The main goal of articular regenerative medicine is to improve the anatomical or functional condition of diseased joints (Carmona et al 2011). Regenerative joint therapy aims to restore the normal structure and physiology of the articular surface, subchondral bone, ligaments, menisci, synovial membrane and other structures surrounding the affected joints, damaged either by trau- ma, degenerative or inflammatory processes (Fortier and Smith 2008, McIlwraith 2009). To achieve these goals, several biotechnological approaches have been proposed, including: a) gene therapy, b) the use of recombinant or autologous growth factors (GFs), c) the use of cells, d) employing procedures involving synthetic biological matrices, e) the use of cells embedded in synthetic matrices; or a combination of two or more of these therapeutic approaches at the same time (Sutter 2007, Fortier and Smith 2008, Mcllwraith 2009).

\section{GENE THERAPY}

Gene therapy has not been evaluated in naturally occurring joint disease in horses. However, this species has been employed as a research model to understand the clinicopathological and biological effects of gene therapy in experimental osteoarthritis based on an osteochondral defect model (Frisbie et al 2002).

Gene therapy intends to introduce genes into joint cells that are most associated with the disease process, for instance chondrocytes, synoviocytes and leukocytes (Frisbie 2005, Kofron and Laurencin 2005, Zachos and Bertone 2005). Theoretically, the introduction of appropriate genes into these cells will allow an increase of the production of anabolic molecules such as GFs, especially insulin-like growth factor I (IGF-I), bone morphogenetic protein 8 (BMP-8), and anti-inflammatory cytokines such as, IL-1 receptor antagonist (IL-1ra), IL-10 and IL-4, among others (Evans et al 2004, Kofron and Laurencin 2005). Anabolic proteins are used for increasing the metabolic rate of the chondrocytes and subsequently to increase the production of ECM. On the other hand, anti-inflammatory cytokines are used for inducing direct antagonism of IL-1 catabolic effects or for blocking higher inflammation ways, such as the down-regulation of NF-kb.

The introduction of one or more therapeutic genes into a cell or target tissue can be achieved by direct administration of the gene into the tissue (introduction in vivo), or indirectly through its propagation into the tissue (cells) ex vivo. Genes can be introduced by viral vectors (transduction) or by chemical or physical agents (transfection) (Giannoudis et al 2006). The main goal in either case is that the therapeutic gene (cDNA) penetrates the target cell membrane, avoiding the lysosomal degradation machinery, and enters the nucleus, where it may integrate into a chromosome or function as an episome and eventually begin the process of transcription. Finally, the resulting mRNA is translated into the peptide or protein of interest (Giannoudis et al 2006).

Ex vivo transduction is the most efficient method for gene therapy, but is technically more complicated when the intention is to insert a therapeutic gene into a target cell. The viral vectors tested to date include retroviruses, adenoviruses, herpesviruses associated-adenoviruses, and 
lentiviruses (Kofron and Laurencin 2005). These vectors should have the ability to infect cells without affecting their division process, have the capacity to accommodate the cDNA encoding the protein of interest, be easy and inexpensive to produce, be safe and easy to titrate, and they should not provoke an immune response (Kofron and Laurencin 2005, Giannoudis et al 2006).

Transfection in vivo or ex vivo has been developed as an alternative to employing viral agents and their associated problems (Evans et al 2004, Kofron and Laurencin 2005). Non-viral vectors include plasmids, peptides, cationic liposomes (lipofection), DNA-ligand complexes that are recognised and consumed by cellular receptors, high-speed cellular bombardment with DNA-coated gold and cell microinjection (Kofron and Laurencin 2005, Evans et al 2006).

\section{GROWTH FACTORS}

Recombinant growth factors. Growth factors are basically signaling proteins that regulate the metabolism of other cells (Zachos and Bertone 2005, Fortier and Smith 2008). Different in vitro studies performed in explants of equine articular cartilage and chondrocyte cultures have shown that equine recombinant IGF-I represented one of the most promising proteins for further research in animal models and subsequent clinical use in the horse (Fortier et al 2002, Davenport-Goodall et al 2004). In addition, GFs such as basic fibroblast growth factor (bFGF) and transforming growth factor beta 1 (TGF- $\beta_{1}$ ) have also been evaluated (Fox and Stephens 2010, Fox et al 2010). It has been observed in an equine osteochondral defect model that IGF-I accelerates the repair of articular defects (Fortier et al 2002). However, to date, according to the information reviewed by the authors, their use has not been routinely extended to equine practice. It is necessary to clarify that during naturally occurring osteoarthritis, IGF-I synovial fluid concentrations are increased in comparison with levels in healthy joints. However, chondrocytes from OA-affected joints show a decreased biological response to this GF, since IGF-I binding proteins (IGFBP) are also increased in these diseased joints. The IGFBP sequester the IGF-I and prevent its anabolic effect on joint tissues (Zachos and Bertone 2005).

Autologous platelet concentrates (APC) or platelet rich plasma $(P R P)$. Platelets are cytoplasmic fragments derived from bone marrow megakaryocytes. Platelets are a source of several GFs and other proteins that stimulate tissue repair, reduce inflammation, induce chemotaxis in mesenchymal cells, cause cell proliferation and cell differentiation, and favor neovascularization and ECM deposition (Argüelles et al 2006, Fortier and Smith 2008, Carmona et al 2009, DeRossi et al 2009, Maia et al 2009, McIlwraith 2009, Bosch et al 2010). The main growth factors released by platelets include TGF- $\beta_{1}$, TGF- $\beta_{2}$, growth factors derived from platelets (PDGF), IGF-I, epidermal growth factor (EGF), hepatocyte growth factor (HGF), among others (Carson and Roach 2002, Anitua et al 2004, Argüelles et al 2006, Carmona et al 2011). Technically, an APC is considered a plasma concentrate with platelets and leukocytes. Normally, an APC contains between 300 and $400 \times 10^{3}$ platelets per mL of plasma, and its leukocyte concentration is similar to that of whole blood (Argüelles et al 2006), or lower.

There is scarce information about the complex molecular mechanism which PRP acts in a positive fashion in patients with OA. However, such as it was above mentioned, GFs contained in PRP, such as VEGF, HGF, PDGF, TGF- $\beta_{1}$ and IGF-I have beneficial effects for cartilage and synovial membrane afflicted with OA. Angiogenic GFs, such as VEGF, HGF and, PDGF increase the vascularization of these tissues with the subsequent increase of the metabolic rate of the constitutive cells. PDGF and TGF- $\beta_{1}$ are chemotaxic for stem cells, particularly from synovial membrane and, this later protein, also induces differentiation of these cells to chondrocytes. Finally, TGF- $\beta_{1}$, PDGF and IGF-I acts as anti-inflammatory and anabolic proteins by direct down-regulation of NF-kb (Carson and Roach 2002, Anitua et al 2004, Argüelles et al 2006, Carmona et al 2011).

The first study in which horse platelets and consequently their GFs were concentrated by the tube method was described by Arguelles et al. (Argüelles et al 2006). In another study, Carmona et al. (2009) described the treatment of 4 horses with OA in different joints with APC. The results were promising, as the degree of lameness and synovial effusion were reduced for more than 8 months. This study did not include a control group, therefore the authors could only conclude that intra-articular injection of APC in horses with degenerative joint disease was safe (Carmona et al 2009).

A study by Abellanet (2009) evaluated the clinical effects of intra-articular injection of APC in horses with OA (30 treated horses and 12 untreated). Clinical improvement was observed in $75 \%$ of treated horses vs. $0 \%$ in the control group. The recurrence rate in this study was $30 \%$. The horses that relapsed had severe radiographic abnormalities, primarily free bone fragments greater than $4 \mathrm{~mm}$ (Abellanet 2009). All these studies confirm the positive results found in humans with platelet concentrates as a treatment for OA in its early stages (Sánchez et al 2012, Spaková et al 2012).

Moreover, new reports show that the clinical use of APC acts positively on other tissues such as tendons, ligaments, muscles and skin with naturally occurring damage or experimentally induced lesions (Abellanet 2009, DeRossi et al 2009, Maia et al 2009, Bosch et al 2010, Lopez et al 2010). The approach has won great acceptation among equine practitioners, since platelet related products can be obtained from the same patient (autologous) by using different procedures or devices un- 
der field conditions and are themselves free of adverse effects (Schnabel et al 2007, Bosch et al 2010). The use of APC opens a new era in the treatment of musculoskeletal diseases in the horse. To date, several manual protocols (DelBue et al 2007, Textor et al 2011, Torricelli et al 2011) and semi-automated devices (Schnabel et al 2007, DeRossi et al 2009, Monteiro et al 2009) for concentrating equine platelets have been described and some of them have been used clinically in horses with musculoskeletal disease (Monteiro et al 2009, Bosch et al 2010, Textor et al 2011). However, more research focused on the cellular and molecular effects of these autologous biopharmaceuticals is needed.

Autologous Conditioned Serum (ACS). IL-1 appears to be the most important catabolic protein in the development of OA (Dinarello 2011). Therefore, blockade of the cellular receptor for IL-1 might mitigate the signs of this disease. Within the IL-1 family there exists a protein that antagonises this function, which is IL-1 receptor antagonist (IL-1ra) or IRAP (Malemud 2010). Recently, the effect of autologous conditioned serum (with glass-chromium beads) was evaluated in an experimental model of equine OA (Wehling et al 2007). It has been observed that equine or human serum conditioned with chromium stimulates supraphysiological production of IL-1ra and other GFs and cytokines (IL-10, IL-1, TNF- $\alpha$, IGF-1, and TGF- $\beta_{1}$, amongst others) (Baltzer et al 2009, Hraha et al 2011).

In theory, IL-1ra blocks the catabolic effect of IL-1 in the joint space (Frisbie 2005). In one investigation it was concluded that horses treated with ACS did better clinically and showed a greater degree of joint repair than the control group (Frisbie et al 2005, Wehling et al 2007). However, the clinical results of the study were less positive than those observed in the same animal model in which IL-1ra gene therapy was evaluated (Frisbie et al 2002). In other studies, 4 doses (at 7-day intervals) were found to be sufficient to reduce the degree of lameness and decrease synovial hyperplasia thanks the increased level of IL-1ra; no adverse effects of this treatment were seen (Frisbie et al 2007).

Some equine practitioners believe that this therapy, which is very expensive because it requires sterile disposable kits, an incubator and a specialized centrifuge (Hraha et al 2011), should be reserved for cases where conventional therapy has failed (Fox and Stephens 2010). In the market, some of the products available are Orthokine $^{\circledR 1}$ (Wehling et al 2007, Baltzer et al 2009), IRAP $^{\circledR 2}$ and IRAP II ${ }^{\circledR 3}$ (Hraha et al 2011).

\footnotetext{
Orthogen AG, Düsseldorf, Germany

Dechra, Düsseldorf, Germany

Arthrex, Bonita Springs, Florida USA
}

\section{CELL-BASED THERAPIES}

Allogenic and autologous chondrocyte transplantation. A research team from Cornell University created a bank of chondrocytes obtained from horses euthanized for reasons other than joint disease (Nixon et al 1992, Hendrickson et al 1994). Chondrocytes are obtained by digestion of the surrounding extracellular matrix with collagenase and can be expanded in vitro. These cells have been used experimentally in the horse, embedded in fibrin matrices (Frisbie 2005). These researchers recommended the use of allogenic chondrocytes, since these cells have low immunogenicity and a high capacity for replication. However, it needs to be said that more than $80 \%$ of the chondrocytes implanted in the joint defects died or disappeared from the defect site over a period of 6-8 months (Nixon et al 1992, Sams and Nixon 1995). It is believed that the main effect of these cells is immunomodulatory and that they accelerate joint repair mechanisms by stimulating resident cells (Sams and Nixon 1995).

In the mid-90s, a surgical technique was introduced in humans called autologous chondrocyte implantation (ACI), involving the removal of healthy chondrocytes and reinsertion after expansion outside the body into joint defects in the same patient (Peterson et al 2002). Frisbie and his team used this technique in horses (Frisbie et al 2008). Autologous cartilage from the lateral trochlear ridge of the femur was arthroscopically harvested in 15 horses aged 3 years. Chondrocytes were isolated, expanded and cultured on a collagen membrane (porcine small intestinal submucosa), and then reinserted into articular defects of $15 \mathrm{~mm}^{2}$ on the medial trochlear ridge of the femur in the opposite femoropatellar joint. The histological and immunohistochemical results showed that the ACI treated group scored overall subjectively better compared with horses in the untreated group, or the group treated with collagen membrane alone after 12 and 18 months (Frisbie et al 2008).

In another study using a similar equine model, it was noticed that the use of this technique also enhanced the content of proteoglycans and collagen type II, as well as improving the appearance of the cartilage surface (Nixon et al 2011). Studies in vitro have shown differences in both cellular and structural characteristics in zones at various depths of the articular cartilage. It is thought that implants with a zonal structure could improve the quality of autologous implants by improving the structure of the newly formed cartilage and by avoiding the complications of classic ACI, such as formation of a fibrous repair tissue rather than hyaline cartilage and separation of the periosteal flap from the surrounding cartilage (Schuurman et al 2009).

Mesenchymal stem cells. The use of mesenchymal stem cells (MSC) to treat degenerative diseases has been one of the most controversial topics in clinical medicine and 
bioethics in recent times, especially when these cells are applied in humans (Barry and Murphy 2004, Colleoni et al 2009). MSC can differentiate into almost any type of adult cell (multidifferential potential), such as neurons and hepatocytes. However, these cells have an inherent ability to transform into chondrocytes, osteoblasts, fibroblasts and adipocytes, amongst others (Baksh et al 2004, Barry and Murphy 2004, Sutter 2007, Fortier and Smith 2008, Colleoni et al 2009, Fox et al 2010).

MSC can be found in any tissue, but abound in blood, adipose tissue, umbilical cord, and especially in bone marrow (Barry and Murphy 2004, Richardson et al 2007, Colleoni et al 2009, Fox et al 2010). Currently, MSC have also been found in others tissues such as embryonic tissue (Paris and Stout 2010), amniotic fluid and Wharton's jelly (Iacono et al 2012). In the horse, as well as in other species, mesenchymal cells can be obtained from any of these sites. However, these cells must meet certain characteristics, such as having the potential for self-renewal, the ability to generate identical copies of themselves through periods of mitotic division as well as the potential for growth in vitro (Baksh et al 2004, Fox et al 2010). Once obtained, the MSC are expanded in vitro and used clinically. It is believed that the tissue environment in which these cells are applied induces their differentiation (Smith et al 2003, Richardson et al 2007, Guest et al 2008, Crovace et al 2010).

The differentiation of MSC into chondrocytes requires that these cells be challenged with TGF- $\beta_{1}$ and other GFs, such as IGF-I and bFGF (Fox et al 2010). Additionally, it is important that these cells be cultured in a 3D matrix to avoid their dedifferentiation to fibroblasts. The most commonly used matrices include those formed with fibrin or polydioxanone. It must be noted that donor age, tissue type, medium and culture time all influence the quality and quantity of the obtained cells (Colleoni et al 2009).

The majority of clinical experience with the use of MSC in horses comes from the treatment of tendon and ligament injuries (Smith et al 2003, Richardson et al 2007, Guest et al 2008, Crovace et al 2010, Guest et al 2010, Watts et al 2011, Marfe et al 2012).

MSC have also been studied and employed for articular cartilage repair in horses (Wilke et al 2007, Frisbie et al 2009). However, there are only a few and disappointing studies in this regard. In one study it was concluded that at short notice stem cells produced an improvement of the induced articular defects. However, this therapeutic effect was not observed when long-term evaluations (8 months) were performed (Wilke et al 2007).

In another study, 24 horses with induced carpal OA were treated with adipose-derived stromal vascular fraction and bone marrow-derived MSC. The authors found that these cells produced increased concentrations of $\mathrm{PGE}_{2}$ in synovial fluid in both groups of horses. Further, in the animals treated with cells derived from adipose tissue increased concentrations of TNF- $\alpha$ were found in the synovial fluid. The authors concluded that under the conditions of their animal model, the use of these cells as a treatment for OA could not be recommended (Frisbie et al 2009).

McCarthy et al (2012) compared equine articular cartilage progenitor cells (ACPC) with equine bone marrow-derived stromal cells (BMSC) cultured in an in vitro system. ACPC and BMSC have demonstrated functional equivalence in their multipotent differentiation capacity. Chondrogenic induction of BMSC resulted in hypertrophic cartilage with limited repair capacity that was predisposed to mineralisation. These changes were not produced by ACPC. According to these findings, ACPC could be considered superior to BMSC with respect to the production of cartilage with functional repair capacity (McCarthy et al 2012).

A recent study found that joints from healthy horses responded similarly to the injection of autologous and allogenic MSC. Injection of allogenic MSC did not generate a systemic response. Intra-articular injection of both types of MSC elicited synovial swelling, but there were no significant differences between the synovial effects of allogenic or autologous cells. These results open a new avenue for the treatment of joint diseases with allogenic stem cell therapies (Carrade et al 2011).

\section{DISCUSSION AND CONCLUSION}

Joint regeneration is a long-term clinical goal/working paradigm that is likely decades away from being accomplished, if ever. Certainly, the horse is one of the best models for understanding the biochemistry of the main arthropathies affecting human beings and their response to regenerative treatments. However, very little data have been obtained through controlled experimentation in equine patients with natural disease. Various conditions related to the owner and the patient itself limit rational experimentation on naturally occurring arthropathies in the horse. Not all patients have the same degree of joint disease and it is nearly impossible to acquire a group of horses with joint disease with a minimum level of clinical and biochemical homogeneity. Nevertheless, all researchers who are passionate about the topic of equine arthropathies and similar diseases should be open for data from patients truly suffering any degree of joint disease, as they may lead to better understanding of the responses to different kinds of regenerative treatments.

The use of gene therapy and recombinant growth factors has lost popularity, due to their difficulty in preparation, high costs and possible side effects. The potential employment of APC (PRP) should be heavier researched, since there is a plethora of methods for producing these substances. Each of these will produce a product with a different cellular and growth factor profile that, consequently, will produce a different joint response. Fur- 
ther, proteomic and genomic studies will be necessary for elucidating the complete mechanism of action of this substance, since to now only small pieces of the puzzle become to explain the effects of PRP in patients with degenerative arthropaties.

With regard to MSC, another debate is ongoing: "the use of autologous vs. allogenic cells." Autologous stem cells carry potentially less risk of tumor development, such as teratomas, in treated tissue (Guest et al 2010) and incite less or no response by the body against the applied cells. The use of allogenic stem cells is very advantageous both time wise and cost wise. In addition, when allogenic stem cells are used, donor site morbidity associated with invasive procedures in the host does not occur, compared with the autologous approach (Shimomura et al 2010). Furthermore, it is as yet unknown whether MSC directly applied to an environment full of pro-inflammatory and catabolic substances function successfully or die (Zhang et al 2005). Other inevitable questions emerge when MSC are considered: do the cells need to be injected, or just the GFs released from the MSC, or even the culture media? (Kurazumi et al 2011, Cargnoni et al 2012, Oshimori and Fuchs 2012, Ryu et al 2013).

Finally, in spite of the booming interest and research effort in regenerative therapy of recent years, we have to conclude that the large amount of information collected in the last decade still is insufficient and further research is needed in this exciting field.

\section{ACKNOWLEDGEMENTS}

This work is partly supported by a scholarship for Catalina López from Programa de Formación Doctoral "Francisco José de Caldas" and a scholarship for Javier A. Sandoval from Programa Jóvenes Investigadores e Innovadores "Virginia Gutiérrez de Pineda", from the Departamento Administrativo de Ciencia, Tecnología e Innovación de Colombia, COLCIENCIAS, and Universidad de Caldas, Manizales, Colombia. The authors thank Piero Borzini for the technical review of the manuscript.

\section{REFERENCES}

Abellanet I. 2009. La terapia de lesiones de tejidos blandos y articulaciones con plasma rico en plaquetas en caballos de deporte: evidencia clínica y bioquímica que valida su utilización. Tesis Doctoral, Facultad de Veterinaria, Universidad Autonoma de Barcelona, España.

Anitua E, I Andia, B Ardanza, P Nurden, AT Nurden. 2004. Autologous platelets as a source of proteins for healing and tissue regeneration. Thromb Haemost 91, 4-15.

Argüelles D, JU Carmona, F Climent, M Prades, R Soler, F Vidal, L Orozco. 2005. Autologous platelet-rich plasma injected intraarticularly diminished synovial effusion and degree of lameness in horses affected with severe joint disease. 14th Annual Scientific Meeting of the European College of Veterinary Surgeons, Lyon, France.

Argüelles D, JU Carmona, J Pastor, A Iborra, L Viñals, P Mar- tínez, E Bach, M Prades. 2006. Evaluation of single and double centrifugation tube methods for concentrating equine platelets. Res Vet Sci 81, 237-245.

Baksh R, L Song, RS Tuan. 2004. Adult mesenchymal stem cells: characterization, differentiation, and application in cell and gene therapy. J Cell Mol Med 8, 301-316.

Baltzer AWA, C Moser, SA Jansen, R Krauspe. 2009. Autologous conditioned serum (Orthokine) is an effective treatment for knee osteoarthritis. Osteoarthr Cartilage $17,152-160$.

Barry FP, JM Murphy. 2004. Mesenchymal stem cells: clinical applications and biological characterization. Int $\mathrm{J}$ Biochem Cell Biol 36, 568-584.

Bosch G, HTM van Schie, MW de Groot, JA Cadby, CHA van de Lest, A Barneveld, PR van Weeren. 2010. Effects of platelet-rich plasma on the quality of repair of mechanically induced core lesions in equine superficial digital flexor tendons: a placebo-controlled experimental study. J Orthop Res 28, 211-217.

Byron CR, MC Stewart, AA Stewart, HC Pondenis. 2008. Effects of clinically relevant concentrations of glucosamine on equine chondrocytes and synoviocytes in vitro. Am $J$ Vet Res 69, 1129-1134.

Cargnoni A, L Ressel, D Rossi, A Poli, D Arienti, G Lombardi, O Parolini. 2012. Conditioned medium from amniotic mesenchymal tissue cells reduces progression of bleomycininduced lung fibrosis. Cytotherapy 14, 153-161.

Carmona JU, CE Giraldo. 2007. Fisiopatología y tratamiento convencional de la osteoartritis en el caballo. Vet Zootec 1, 60-73.

Carmona JU, C López, M Prades. 2009. Use of autologous platelet concentrates obtained by the tube method as a treatment for arthropathies in horses. Arch Med Vet 41, 175-179.

Carmona JU, M Prades. 2009. Pathophysiology of osteoarthritis. Comp Equine 4, 28-40.

Carmona JU, C López, M Prades. 2010. Determinación de marcadores inflamatorios y anabólicos articulares en caballos jóvenes estabulados con osteocondrosis tarsocrural. Rev MVZ Córdoba 15, 1907-1915.

Carmona JU, C López, C Giraldo. 2011. Uso de concentrados autólogos de plaquetas como terapia regenerativa de enfermedades crónicas del aparato músculo-esquelético equino. Arch Med Vet 43, 1-10.

Carrade DD, SD Owens, LD Galuppo, MA Vidal, GL Ferraro, F Librach, S Buerchler, MS Friedman, NJ Walker, DL Borjesson. 2011. Clinicopathologic findings following intra-articular injection of autologous and allogeneic placentally derived equine mesenchymal stem cells in horses. Cytotherapy 13, 419-430.

Carson N, RB Roach. 2002. Platelet-rich plasma: Clinical applications in dentistry. J Am Dent Assoc 133, 1383-1386.

Colleoni S, E Bottani, I Tessaro, G Mari, B Merlo, N Romagnoli, A Spadari, C Galli, G Lazzari. 2009. Isolation, growth and differentiation of equine mesenchymal stem cells: effect of donor, source, amount of tissue and supplementation with basic fibroblast growth factor. Vet Res Commun 33, 811-821.

Coudry V, D Thibaud, B Riccio, F Audigié, D Didierlaurent, J Denoix. 2007. Efficacy of tiludronate in the treatment of horses with signs of pain associated with osteoarthritic 
lesions of the thoracolumbar vertebral column. Am J Vet Res 68, 329-337.

Crovace A, L Lacitignola, G Rossi, E Francioso. 2010. Histological and immunohistochemical evaluation of autologous cultured bone marrow mesenchymal stem cells and bone marrow mononucleated cells in collagenase-induced tendinitis of equine superficial digital flexor tendon. Vet Med Int 2010, 1-10.

Davenport-Goodall CL, RC Boston, DW Richardson. 2004. Effects of insulin-like growth factor-II on the mitogenic and metabolic activities of equine articular cartilage with and without interleukin 1-beta. Am J Vet Res 65, 238-244.

DelBue M, S Riccò, V Conti, E Merli, R Ramoni, S Grolli. 2007. Platelet lysate promotes in vitro proliferation of equine mesenchymal stem cells and tenocytes. Vet Res Commun 31, 289-292.

DeRossi R, AC Anciliero, G Silveira, F Oliveira, CR Brito, G Gonçalves, K Bonucielli. 2009. Effects of platelet-rich plasma gel on skin healing in surgical wound in horses. Acta Cir Bras 24, 276-281.

Dinarello CA. 2011. A clinical perspective of IL-1 $\beta$ as the gatekeeper of inflammation. Eur J Immunol 41, 1203-1217.

Evans CH, JN Gouze, E Gouze, PD Robbins, SC Ghivizzani. 2004. Osteoarthritis gene therapy. Gene Ther 11, 379-389.

Evans CH, SC Ghivizzani, PD Robbins. 2006. Gene therapy for arthritis. What next? Arthritis Rheum 54, 1714-1729.

Fortier LA, HO Mohammed, G Lust, AJ Nixon. 2002. Insulinlike growth factor-I enhances cell-based repair of articular cartilage. J Bone Joint Surg Br 84-B, 276-288.

Fortier LA, RKW Smith. 2008. Regenerative medicine for tendinous and ligamentous njuries of sport horses. Vet Clin North Am Equine Pract 24, 191-201.

Fox BA, MM Stephens. 2010. Treatment of knee osteoarthritis with Orthokine ${ }^{\circ}$ - derived autologous conditioned serum. Expert Rev Clin Inmunol 6, 335-345.

Fox DB, JJ Warnock, AM Stoker, JK Luther, M Cockrell. 2010. Effects of growth factors on equine synovial fibroblasts seeded on synthetic scaffolds for avascular meniscal tissue engineering. Res Vet Sci 88, 326-332.

Frisbie DD. 2005. Future directions in treatment of joint disease in horses. Vet Clin North Am Equine Pract 21, 713-724.

Frisbie DD, CE Kawcak, CW McIIwraith. 2005. Evaluation of autologous conditioned serum using an experimental model of equine osteoarthritis. Am Assoc Equine Pract Proceedings, Lameness in the performance horse, $\mathrm{Pp}$ 374-375.

Frisbie DD, SC Ghivizzani, PD Robbins, CH Evans, CW McIlwraith. 2002. Treatment of experimental equine osteoarthritis by in vivo delivery of the equine interleukin-1 receptor antagonist gene. Gene Ther 9, 1 12-20.

Frisbie DD, CE Kawcak, NM Werpy, RD Park, CW McIlwraith. 2007. Clinical, biochemical, and histologic effects of intra-articular administration of autologous conditioned serum in horses with experimentally induced osteoarthritis. Am J Vet Res 68, 290-296.

Frisbie DD, SM Bowman, HA Colhoun, EF DiCarlo, CE Kawcak, CW McIlwraith. 2008. Evaluation of autologous chondrocyte transplantation via a collagen membrane in equine articular defects - results at 12 and 18 months. Osteoarthr Cartilage 16, 667-679.

Frisbie D, J Kisiday, CE Kawcak, N Werpy, CW McIlwraith.
2009. Evaluation of adipose-derived stromal vascular fraction or bone marrow-derived mesenchymal stem cells for treatment of osteoarthritis. J Orthop Res 27, 1675-1680.

Giannoudis PV, CC Tzioupis, E Tsiridis. 2006. Gene therapy in orthopaedics. Injury 37 Suppl 1, S30-40.

Gough MR, D Thibaud, RKW Smith. 2010. Tiludronate infusion in the treatment of bone spavin: A double blind placebo-controlled trial. Equine Vet J 42, 381-387.

Guest DJ, MR Smith, WR Allen. 2008. Monitoring the fate of autologous and allogeneic mesenchymal progenitor cells injected into the superficial digital flexor tendon of horses: Preliminary study. Equine Vet J 40, 178-181.

Guest DJ, MRW Smith, WR Allen. 2010. Equine embryonic stem-like cells and mesenchymal stromal cells have different survival rates and migration patterns following their injection into damaged superficial digital flexor tendon. Equine Vet J 42, 7 636-642.

Hendrickson DA, AJ Nixon, DA Grande, RJ Todhunter, RM Minor, H Erb, G Lust. 1994. Chondrocyte-fibrin matrix transplants for resurfacing extensive articular cartilage defects. J Orthop Res 12, 485-497.

Hraha TH, KM Doremus, CW McIlwraith, DD Frisbie. 2011. Autologous conditioned serum: The comparative cytokine profiles of two commercial methods (IRAP and IRAP II) using equine blood. Equine Vet J 43, 516-521.

Iacono E, L Brunori, A Pirrone, PP Pagliaro, F Ricci, PL Tazzari, B Merlo. 2012. Isolation, characterization and differentiation of mesenchymal stem cells from amniotic fluid, umbilical cord blood and Wharton's jelly in the horse. Reproduction 143, 455-468.

Kofron MD, CT Laurencin. 2005. Orthopaedic applications of gene therapy. Curr Gene Ther 5, 37-61.

Kurazumi H, M Kubo, M Ohshima, Y Yamamoto, Y Takemoto, R Suzuki, S Ikenaga, A Mikamo, K Udo, K Hamano, T-S Li. 2011. The effects of mechanical stress on the growth, differentiation, and paracrine factor production of cardiac stem cells. PLOS ONE 6, 1-8.

Lopez C, JU Carmona, I Samudio. 2010. Uso de concentrados autólogos de plaquetas como tratamiento de una fractura escapular y una lesión del plexo braquial producidas por un disparo en un caballo. Arch Med Vet 42, 209-214.

Maia L, MV de Souza, GES Alves, JIR Júnior, AC de Oliveira, BM Zandim, YFR da Silva. 2009. Plasma rico em plaquetas no tratamento de tendinite induzida em eqüinos: avaliação ultra-sonográfica. Pesq Vet Bras 29, 241-245.

Malemud C. 2010. Anticytokine therapy for osteoarthritis. Drugs Aging 27, 95-115.

Malone ED. 2002. Managing chronic arthritis. Vet Clin North Am Equine Pract 18, 411-437.

Marfe G, G Rotta, L De Martino, M Tafani, F Fiorito, C Di Stefano, M Polettini, M Ranalli, MA Russo, A Gambacurta. 2012. A new clinical approach: Use of blood-derived stem cells (BDSCs) for superficial digital flexor tendon injuries in horses. Life Sci 90, 825-830.

McCarthy HE, JJ Bara, K Brakspear, SK Singhrao, CW Archer. 2012. The comparison of equine articular cartilage progenitor cells and bone marrow-derived stromal cells as potential cell sources for cartilage repair in the horse. Vet $J$ 192, 345-351.

McIlwraith CW. 2008. Use of equine models to evaluate articular cartilage repair. Eur Cell Mat 16, 32. 
McIlwraith CW. 2009. Osteoarthritis (Degenerative Joint Disease) - An Update. Proceedings of the $11^{\text {th }}$ International Congress of the World Equine Veterinary Association, Guarujá, SP, Brazil, Pp 1-5

Monteiro SO, OM Lepage, CL Theoret. 2009. Effects of platelet-rich plasma on the repair of wounds on the distal aspect of the forelimb in horses. Am J Vet Res 70, 277-282.

Neil KM, MW Orth, PM Coussens, PS Chan, JP Caron. 2005. Effects of glucosamine and chondroitin sulfate on mediators of osteoarthritis in cultured equine chondrocytes stimulated by use of recombinant equine interleukin-1beta. Am J Vet Res 66, 1861-1869.

Nixon AJ, G Lust, M Vernier-Singer. 1992. Isolation, propagation, and cryopreservation of equine articular chondrocytes. Am J Vet Res 53, 2364-2370.

Nixon AJ, L Begum, HO Mohammed, B Huibregtse, MM O'Callaghan, GL Matthews. 2011. Autologous chondrocyte implantation drives early chondrogenesis and organized repair in extensive full- and partial-thickness cartilage defects in an equine model. J Orthop Res 29, 1121-1130.

Oshimori N, E Fuchs. 2012. Paracrine TGF- $\beta$ signaling counterbalances BMP-mediated repression in hair follicle stem cell activation. Cell Stem Cell 10, 63-75.

Paris DBBP, TAE Stout. 2010. Equine embryos and embryonic stem cells: Defining reliable markers of pluripotency. Theriogenology 74, 516-524.

Patan-Zugaj B, J Edinger. 2009. Degenerative joint disease (osteoarthritis). Praktische Tierarzt 90, 18-28.

Peterson L, M Brittberg, I Kiviranta, EL Åkerlund, A Lindahl. 2002. Autologous chondrocyte transplantation: Biomechanics and long-term durability. Am J Sports Med 30, 2-12.

Reynard LN, J Loughlin. 2012. Genetics and epigenetics of osteoarthritis. Maturitas 71, 200-204.

Richardson LE, J Dudhia, PD Clegg, R Smith. 2007. Stem cells in veterinary medicine - attempts at regenerating equine tendon after injury. Trends Biotechnol 25, 409 - 416.

Ryu JC, BP Davidson, A Xie, Y Qi, D Zha, JT Belcik, ES Caplan, JM Woda, CC Hedrick, RN Hanna, N Lehman, Y Zhao, A Ting, JR Lindner. 2013. Molecular imaging of the paracrine proangiogenic effects of progenitor cell therapy in limb ischemia. Circulation 127, 710-719.

Sams AE, AJ Nixon. 1995. Chondrocyte-laden collagen scaffolds for resurfacing extensive articular cartilage defects. Osteoarthr Cartilage 3, 47-59.

Sánchez M, J Guadilla, N Fiz, I Andia. 2012. Ultrasound-guided platelet-rich plasma injections for the treatment of osteoarthritis of the hip. Rheumatology 51, 144-150.

Sandell LJ. 2012. Etiology of osteoarthritis: genetics and synovial joint development. Nat Rev Rheumatol 8, 77-89.

Schnabel LV, HO Mohammed, BJ Miller, WG McDermott, MS Jacobson, KS Santangelo, LA Fortier. 2007. Platelet rich plasma (PRP) enhances anabolic gene expression patterns in flexor digitorum superficialis tendons. J Orthop Res 25, 230-240.
Schuurman W, D Gawlitta, TJ Klein, Wt Hoope, MHP van Rijen, WJA Dhert, PR van Weeren, J Malda. 2009. Zonal chondrocyte subpopulations reacquire zone-specific characteristics during in vitro redifferentiation. Am J Sports Med 37, suppl 97S-104S.

Sellam J, F Berenbaum. 2010. The role of synovitis in pathophysiology and clinical symptoms of osteoarthritis. Nat Rev Rheumatol 6, 625-635.

Shimomura K, W Ando, K Tateishi, R Nansai, H Fujie, DA Hart, H Kohda, K Kita, T Kanamoto, T Mae, K Nakata, K Shino, H Yoshikawa, N Nakamura. 2010. The influence of skeletal maturity on allogenic synovial mesenchymal stem cell-based repair of cartilage in a large animal model. Biomaterials 31, 8004-8011.

Shoemaker R. 2004. Osteoarthritis of the distal tarsal joints (bone spavin) in the horse. Large Animal Veterinary Rounds 4, 2.

Smith RKW, M Korda, GW Blunn, AE Goodship. 2003. Isolation and implantation of autologous equine mesenchymal stem cells from bone marrow into the superficial digital flexor tendon as a potential novel treatment. Equine Vet $J$ 35, 1 99-102.

Spaková T, J Rosocha, M Lacko, D Harvanová, A Gharaibeh. 2012. Treatment of knee joint osteoarthritis with autologous platelet-rich plasma in comparison with hyaluronic acid. Am J Phys Med Rehabil 91, 411-417

Sutter WW. 2007. Autologous cell-based therapy for tendon and ligament injuries. Clin Tech Equine Pract 6, 198-208.

Textor JA, JW Norris, F Tablin. 2011. Effects of preparation method, shear force, and exposure to collagen on release of growth factors from equine platelet-rich plasma. Am J Vet Res 72, 271-278.

Torricelli P, M Fini, G Filardo, M Tschon, M Pischedda, A Pacorini, E Kon, R Giardino. 2011. Regenerative medicine for the treatment of musculoskeletal overuse injuries in competition horses. Int Orthop (SICOT) 35, 1569-1576.

Watts A, A Yeager, O Kopyov, A Nixon. 2011. Fetal derived embryonic-like stem cells improve healing in a large animal flexor tendonitis model. Stem Cell Res Ther 2, 4.

Wehling P, C Moser, D Frisbie, CW McIlwraith, CE Kawcak, R Krauspe, JA Reinecke. 2007. Autologous conditioned serum in the treatment of orthopedic diseases: the orthokine therapy. Biodrugs 21, 323-332.

Wilke MM, DV Nydam, AJ Nixon. 2007. Enhanced early chondrogenesis in articular defects following arthroscopic mesenchymal stem cell implantation in an equine model. $J$ Orthop Res 25, 913-925.

Zachos TA, AL Bertone. 2005. Growth factors and their potential therapeutic applications for healing of musculoskeletal and other connective tissues. Am J Vet Res 66, 727-738.

Zhang X, M Haaf, B Todorich, E Grosstephan, H Schieremberg, N Surguladze, JR Connor. 2005. Cytokine toxicity to oligodendrocyte precursors is mediated by iron. Glia 52, 3 199-208. 